\title{
Lung-restricted Activation of the Alveolar Macrophage/Monocyte System in Pulmonary Sarcoidosis ${ }^{1-3}$
}

\author{
JOACHIM MÜLLER-QUERNHEIM, SIBYLLE PFEIFER, DANIELA MÄNNEL, \\ JÁNOS STRAUSZ, and RUDOLF FERLINZ
}

Introduction
Tumor necrosis factor $\alpha(\mathrm{TNF} \alpha)$ plays a key role as a mediator of inflammation and cellular immune response. It is primarily produced and secreted by activated macrophages and monocytes and exhibits an extensive array of biologic activities. In addition to exerting a direct cytotoxic effect on tumor cells, it attracts and activates a variety of other cells, thus enhancing the inflammatory and immune processes (1). TNF $\alpha$ apparently shares several bioactivities with interleukin-1 (IL-1), and it is capable of inducing IL-1 release (1). Interactions of interleukin-2 (IL-2) and its receptor (IL$2 R$ ) with $T N F \alpha$ have recently been described by several investigators demonstrating the induction of TNF $\alpha$ production in monocytes and macrophages by IL-2 (2) as well as the regulation of DNAbinding proteins by TNF $\alpha$, which control IL-2 receptor gene activation in human T-cells $(1,3)$.

The most characteristic features of pulmonary sarcoidosis are noncaseating granuloma and a T-lymphocyte/mononuclear phagocyte alveolitis. Despite the systemic nature of the disease, activated T-cells are observed only in the affected organs, whereas T-cells of the peripheral blood remain quiescent (4-8). Evidence of T-cell activation has been provided by the spontaneous release of such mediators as $\gamma$-interferon and IL-2, which recruit and activate mononuclear phagocytes, resulting in the subsequent release of IL-1 and TNF $\alpha(9,10)$. Several studies have demonstrated that macrophagederived IL-1 and TNF $\alpha$ play an important role in the induction and sustenance of the granuloma (11).

Detailed analyses of the contribution of activated T-cells to the inflammatory process of sarcoidosis are provided by the literature. However, the alveolar macrophages represent the dominating cell population in sarcoid alveolitis. These cells are also activated and release medi-

\begin{abstract}
SUMMARY An activation of T-celis that is restricted to the lung has been demonstrated in pulmonary sarcoidosis. The role of blood monocytes (MO) and alveolar macrophages (AM) in this concept of compartmentalized inflammation has not yet been evaluated. In order to elucidate this question, we measured the release of tumor necrosis factor $\alpha$ (TNF $\alpha$ ) and interleukin-1 (IL-1) by peripheral blood mononuclear cells (PBMNC) and AM in 43 patients with sarcoldosis (32 with active, 11 with inactive disease) without therapy and correlated the spontaneous monokine release to parameters of the T-cell alveolitis and the course of the disease. TNF $\alpha$ as well as IL-1 were spontaneously released by $A M$ of the active group, i.e., $2,385 \pm 735 \mathrm{pg} / \mathrm{ml} / 10^{6}$ cells/24 $\mathrm{h}$ and $7 / 12$ (IL-1 ${ }^{+} / \mathrm{total}$ ), respectively. Autologous PBMNC were qulescent, releasing only baseline levels of any monokine. AM were not activated in the inactive group, releasing $500 \pm 212 \mathrm{pg} / \mathrm{ml} / 10^{6}$ cells/24 $\mathrm{h} \mathrm{TNF} \alpha$, whereas $1 / 5$ were IL-1-positive ( $<0.05$ in both comparisons), which is within the range of the control group. Kinetic experiments revealed that the TNF $\alpha$ gene of AM is activated in vivo, resulting in TNF $\alpha$ mRNA-positive, TNF $\alpha$-releasing cells that, cultured in vitro, regulate the TNF $\alpha$ gene transcription down and cease to release TNF $\alpha$. Interestingly, there is no stringent correlation between the spontaneous release of TNF $\alpha$ by AM and signs of T-cell activation as soluble interleukin-2 (IL-2) receptor serum concentration, release of IL-2, and expression of IL-2 receptor by alveolar T-cells. Compartmentalized T-cell activation in active pulmonary sarcoidosis is therefore paralleled by the functional activation of AM. Analogous to T-cells of peripheral blood, MO are quiescent. This speaks in favor of a simultaneous activation of immune cells by the inflammatory milieu of the lower respiratory tract.
\end{abstract}

AM REV RESPIR DIS 1992; 145:187-192

ators as well as oxidants $(8-10,12)$. Regarding the activation status of peripheral blood monocytes, only a few studies are available, and conflicting results have been reported. Monitoring the spontaneous $\gamma$-interferon, TNF $\alpha$, and IL-1 release by monocytes, no differences were observed by several investigators between patients with sarcoidosis and normal control subjects $(8,13)$. In marked contrast, an increased release of radical oxidants by sarcoid blood monocytes has been reported (14). Thus, the question of an organ-restricted activation of the mononuclear phagocytes paralleling the compartmentalized activation of sarcoid T-cells remains open. In this context we asked the following questions: (I) Is the activation of alveolar macrophages in sarcoidosis paralleled by the activation of peripheral blood monocytes? (2) Is this activation due to a stimulus from the inflammatory milieu of the lower respiratory tract or is it a constitutive property of these cells? (3) Is there a concordant activation of the alveolar macrophage/ monocyte segment as well as the T-cell segment of the immune system?
As an approach this study evaluates the spontaneous and LPS-induced TNF $\alpha$ and IL-1 release by alveolar macrophages and peripheral blood mononuclear cells of patients with active or inactive sarcoidosis and control subjects. The spontaneous TNF $\alpha$ release was compared with functional parameters of T-cell activation such as release of IL-2, expression of IL-2 receptors on the cell surface, and soluble IL-2 receptor concentration in serum.

(Received in original form May 5, 1991 and in revised form July 31, 1991)

\footnotetext{
${ }^{1}$ From the Division of Pneumology, IIIrd Department of Internal Medicine, Johannes Gutenberg University, Mainz, and the Institute of Immunology and Genetics, German Cancer Research Center, Heidelberg, Germany.

${ }^{2}$ Supported by Grant No. 01KE8804/0 from the Federal Minister of Science and Technology and by the Naturwissen schaftlich-Medizinisches Forschungszentrum, Mainz, Germany.

${ }^{3}$ Correspondence and requests for reprints should be addressed to J. Müller-Quernheim, M.D., Division of Pneumology, Bldg 409, IIIrd Department of Internal Medicine, Johannes Gutenberg University, Langenbeckstrasse, 6500 Mainz, Germany.
} 


\section{Methods}

Study Population

The diagnosis of sarcoidosis was established in 43 patients using defined criteria, including transbronchial biopsy (15). None of the patients received therapy at the time of investigation nor had they within the previous 2 months. For the purpose of this study, the patients were allocated to groups of clinically active or inactive sarcoidosis based on newly observed or progressing pulmonary or general symptoms (dyspnea, cough, fever, arthralgia, uveitis, etc.), new or progressing abnormalities in the pulmonary function test or the chest radiograph. The clinically active group consisted of 32 patients; the clinically inactive group consisted of 11 patients. The clinical characteristics of the two groups are given in table 1. The two groups did not differ in age, sex, or smoking history ( $p>0.02)$. Bronchoalveolar lavage $(B A L)$ revealed equal volumes recovered in both groups, and on average the active group showed a significant increase in lymphocytes $(20.9 \%$ versus $13.4 \%, \mathrm{p}<0.05)$ with an increase in the ratio of CD4 (helper T-cells) to CD8 (suppressor/cytotoxic T-cells) (4.2 in the active versus 2.7 in the inactive group). Eight patients who underwent bronchoscopy for diagnostic reasons and who were free of interstitial lung diseases retrospectively or had benign neoplasia served as control subjects. Peripheral blood was drawn from 18 healthy subjects for control purposes.

\section{Preparation of Bronchoalveolar and Blood Mononuclear Cells}

Bronchoalveolar cells were obtained by BAL as described elsewhere (16). Recovered BAL fluid was filtered and centrifuged at 1,500 rpm, and the cells were washed three times with RPMI 1640 (Seromed, Berlin, Germany). Pure AM $(>95 \%)$ were prepared by subsequent 2 -h plastic adherence (17). Blood was obtained by venipuncture, and mononuclear cells (PBMNC) were isolated by Ficoll $\mathrm{Hy}$ paque gradient centrifugation (17).

\section{Cell Culture}

Cells were resuspended to a final concentration of $10^{6}$ cells/ml in RPMI 1640 with $10 \%$ fetal calf serum (Seromed), $200 \mathrm{mM}$ glutamine (Seromed), 1\% HEPES (Seromed), and $50 \mu \mathrm{g} / \mathrm{ml}$ gentamycin (Seromed). To measure spontaneous TNF $\alpha$ release, cells were cultured without any added stimulus. Control cultures received Salmonella abortus equi endotoxin (LPS) (Sigma, München, Germany), $1 \mu \mathrm{g} / \mathrm{ml}$. The plates were incubated for $24 \mathrm{~h}$, and the supernatants were collected and stored frozen at $-20^{\circ} \mathrm{C}$. To investigate the spontaneous release of TNF $\alpha$ in vitro as a function of time, two cultures were initiated simultaneously. Three hours prior to the end of the culture cells were washed, and fresh culture medium was added. At the end of the culture supernatants were harvested and stored frozen until tested. An additional culture was stimulated with LPS $(1 \mu \mathrm{g} / \mathrm{ml})$ after $6 \mathrm{~h}$ without any

TABLE 1

CHARACTERISTICS OF STUDY POPULATIONS

\begin{tabular}{|c|c|c|}
\hline Symptoms/Parameters & $\begin{array}{c}\text { Active } \\
\text { Sarcoidosis" } \\
(n=32)\end{array}$ & $\begin{array}{c}\text { Inactive } \\
\text { Sarcoidosis } \\
(n=11)\end{array}$ \\
\hline \multicolumn{3}{|l|}{ Chest radiograph } \\
\hline \multicolumn{3}{|l|}{ Bihilar adenopathy } \\
\hline Progressing & $26{ }^{\dagger}$ & 0 \\
\hline Stable/regressing & 4 & 10 \\
\hline \multicolumn{3}{|l|}{ Parenchymal involvement } \\
\hline Progressing & 19 & 0 \\
\hline Stable/regressing & 0 & 1 \\
\hline \multicolumn{3}{|l|}{ Pulmonary function test } \\
\hline \multicolumn{3}{|l|}{ Restrictive lung disease } \\
\hline Progressing & 9 & 0 \\
\hline Stable/regressing & 2 & 2 \\
\hline \multicolumn{3}{|l|}{ Compliance $\mp$} \\
\hline Decreasing & 8 & \\
\hline Stable/increasing & 1 & 2 \\
\hline \multicolumn{3}{|l|}{ DLco $\ddagger$} \\
\hline Decreasing & 7 & \\
\hline Stable/increasing & 3 & 1 \\
\hline \multicolumn{3}{|l|}{ Symptoms } \\
\hline Cough/dyspnea & 21 & 1 \\
\hline Fever & 5 & 0 \\
\hline Arthralgia & 3 & 1 \\
\hline Erythema nodosa & 5 & 0 \\
\hline \multicolumn{3}{|l|}{ Elevated serologic parameters } \\
\hline Angiotensin-converting enzyme & 8 & 1 \\
\hline Neopterin & 14 & 2 \\
\hline \multicolumn{3}{|l|}{ Extrathoracic disease } \\
\hline Uvea & 2 & 0 \\
\hline Liver & 4 & 0 \\
\hline Heart & 1 & 1 \\
\hline Skin & 1 & 0 \\
\hline Nervous system & 4 & 0 \\
\hline
\end{tabular}

stimulus, and the supernatants were harvested after $18 \mathrm{~h}$.

\section{Cytokine Assays}

TNF $\alpha$ was determined using a previously described enzyme-linked immunosorbent assay (ELISA) (18) with slight modifications. Briefly, 96-well flat-bottom plates (Immunoplates; Flow Laboratories, Meckenheim, Germany) were coated with $5 \mu \mathrm{g} / \mathrm{ml}$ monoclonal antirecombinant human TNF $\alpha$ (rhTNF $\alpha$ ) antibody (clone 195; kindly provided by Dr. E. Schlick, Knoll AG, Ludwigshafen, Germany). Serial dilutions of the test samples in phosphate-buffered saline $/ 0.1 \%$ bovine serum albumin (BSA; Merck, Darmstadt, Germany) were applied to the plates for $2 \mathrm{~h}$ afterwards. The captured TNF $\alpha$ was detected by a biotinconjugated protein A (Sigma) purified polyspecific rabbit anti-rhTNF $\alpha$ antibody and streptavidin-peroxidase (Boehringer, Mannheim, Germany). Absorption curves obtained with the test samples were compared with a standard curve obtained with rhTNF $\alpha$ (kindly provided by Dr. E. Schlick, Knoll AG), and the TNF $\alpha$ content was expressed as $\mathrm{pg} / \mathrm{ml}$. The lower limit of sensitivity was $250 \mathrm{pg} / \mathrm{ml}$.

IL-1 was determined using the standard costimulaton assay with thymocytes of $\mathrm{C} 3 \mathrm{H} /$
HeJ mice (19). Alternatively, a commercially available IL-1 ELISA for IL-1 $\beta$ (Interleukin$1 \beta$ ELISA Kit; Cistron, Pine Brook, NJ) was used.

IL-2 biologic activity was determined by the concentration-dependent proliferation of the murine cytotoxic T-lymphocyte line (CTLL). Proliferation was measured by bromodesoxyuridine (BrdU) incorporation detected by an ELISA using a monoclonal antiBrdU antibody (20). The IL-2 units present were quantified by using probit analysis with a $20 \%$ intercept (21) and expressed as international units of $\mathrm{IL}-2$ released by $10^{6} \mathrm{~T}$-cells in BAL. International IL-2 units were derived from an arbitrary IL-2 standard that was calibrated with the International IL-2 Standard (National Institute for Biological Standards and Controls, UK).

\section{Northern Blot}

For Northern analysis total cellular RNA was prepared using guanidine-thiocyanate lysis. RNA samples were size-fractionated by electrophoresis in 1\% agarose gels containing formaldehyde and transferred to nylon filters (Genofit, Heidelberg, Germany). Hybridization was performed as described by using the 750 bp EcoRI-fragment of the coding region 
of human TNF $\alpha$ cDNA as probe. The probe was labeled by the random primer method.

\section{Determination of Soluble $I L-2 R$ in Serum}

The sIL-2R was evaluated by a sandwich enzyme-linked immunosorbent assay (ELISA) employing two monoclonal antibodies directed against different epitopes of the IL-2 receptor (Cellfree Interleukin-2 Receptor Test Kit; T Cell Sciences, Cambridge, MA).

\section{Immunoperoxidase Technique}

BAL cells were fixed on polylysine-coated slides (Bio-Rad Laboratories, Richmond, CA) and developed with a peroxidase-antiperoxidase technique using monoclonal antibodies directed against CD3, CD4, CD8, and CD25 (Ortho Diagnostic Systems, Neckargemünd, Germany) and HLA-DR (Becton Dickinson, Heidelberg, Germany) at concentrations suggested by the suppliers.

\section{Statistical Analysis}

Data are expressed as mean \pm SEM. Comparisons were performed using the Mann Whitney U-test; $p$ values of less than 0.05 were considered significant.

\section{Results}

\section{Monokine Release by Alveolar Macrophages and Peripheral Blood Mononuclear Cells}

Spontaneous TNF $\alpha$ release by AM was found to a significant greater extent in patients with active sarcoidosis than in those with inactive disease (figure 1). The average was $2,385 \pm 735 \mathrm{pg} / \mathrm{ml}$ in the active versus $500 \pm 212 \mathrm{pg} / \mathrm{ml}$ in the inactive group. This difference is of high statistical significance $(p<0.01)$. The AM of the control group released $285 \pm 102$ $\mathrm{pg} / \mathrm{ml} \mathrm{TNFa}$, which is in the range of patients with inactive sarcoidosis $(p>0.02)$. A comparison of TNF $\alpha$ production by AM after stimulation with LPS also showed a significantly higher release in active compared with inactive sarcoidosis $(26,416 \pm 3,283 \mathrm{pg} / \mathrm{ml}$ versus $14,957 \pm$ $3,653 \mathrm{pg} / \mathrm{ml} ; \mathrm{p}<0.05$ ) (figure 1). No difference emerged in comparing patients with inactive disease with control subjects $(17,189 \pm 3,670 \mathrm{pg} / \mathrm{ml} ; \mathrm{p}>0.2)$.

Although lung macrophages from patients with active disease released significantly higher amounts of TNF $\alpha$ than did those from patients with inactive sarcoidosis and control subjects, the autologous PBMNC released comparable quantities in patients with sarcoidosis and in 15 healthy subjects. The spontaneous release was $384 \pm 144 \mathrm{pg} / \mathrm{ml}$ in patients with active, $684 \pm 186 \mathrm{pg} / \mathrm{ml}$ in those with inactive sarcoidosis, and $378 \pm 186$ $\mathrm{pg} / \mathrm{ml}$ in control subjects ( $\mathrm{p}>0.2$ for all
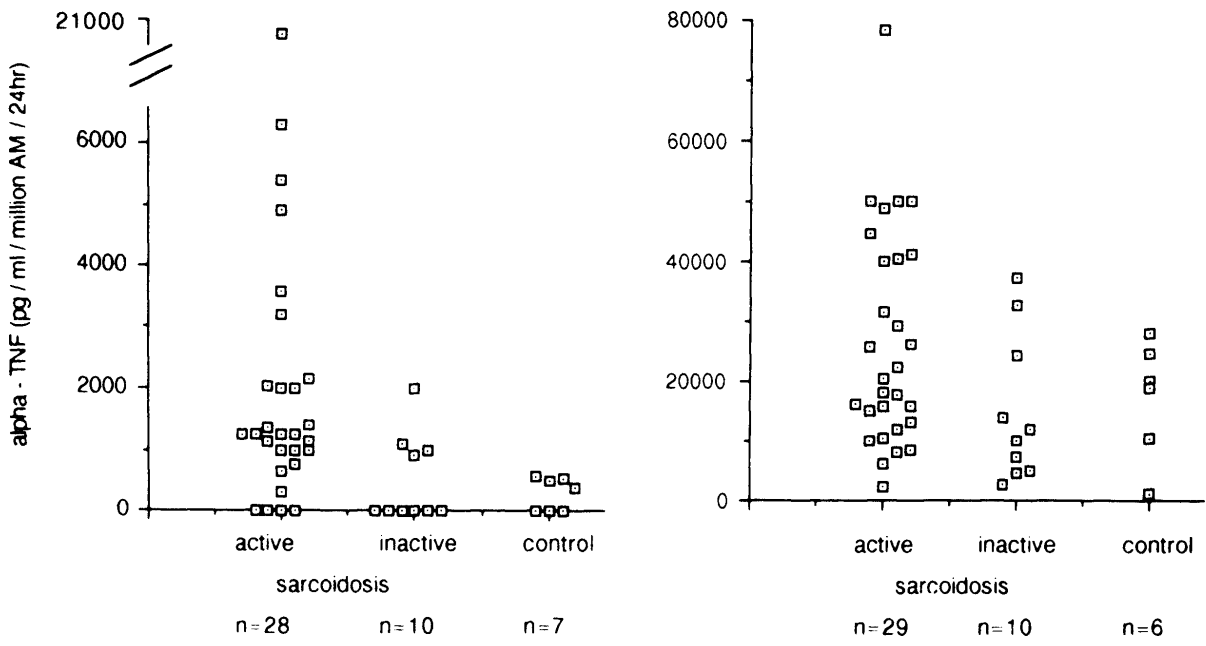

Fig. 1. Spontaneous (left panel) and LPS-induced (right panel) release of TNF $\alpha$ by alveolar macrophages (AM) in patients with sarcoidosis and in control subjects.
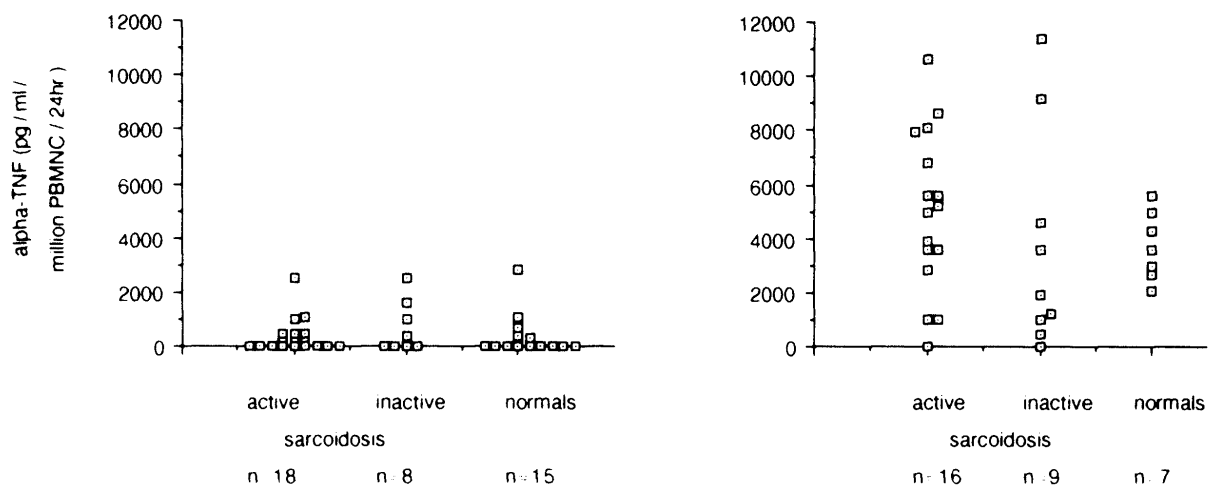

Fig. 2. Spontaneous (left pane/) and LPS-induced (right pane/) release of TNF $\alpha$ by peripheral blood mononuclear cells (PBMNC) in patients with sarcoidosis and in control subjects.

comparisons) (figure 2). The LPS-stimulated release of TNF $\alpha$ by peripheral blood mononuclear cells as well did not differ between the three study groups; $4,959 \pm 722 \mathrm{pg} / \mathrm{ml}$ in patients with active and $3,709 \pm 1,272 \mathrm{pg} / \mathrm{ml}$ in those with inactive sarcoidosis, and 3,725 \pm $449 \mathrm{pg} / \mathrm{ml}$ in normal subjects $(\mathrm{p}>0.2$, for all comparisons) (figure 2).

Spontaneous TNF $\alpha$ release by AM was not only observed in patients with sarcoidosis. Evaluation of TNF $\alpha$ release by AM in patients with idiopathic pulmonary fibrosis (IPF) $(n=9)$ and tuberculosis $(n=2)$ also demonstrated a spontaneous production of TNF $\alpha$ in three of nine patients with IPF (1,023/703/14,000 pg/ $\mathrm{ml})$ and in the two patients with pulmonary tuberculosis $(8,350$ and $1,658 \mathrm{pg} / \mathrm{ml})$. Six of nine patients with IPF and two patients with pneumonia tested negative for spontaneous TNF $\alpha$ release by AM.

In order to determine if the TNF $\alpha$ release in sarcoidosis is paralleled by the release of IL-1, we investigated both spontaneous and LPS-induced IL-1 release by AM and PBMNC of patients with active or inactive sarcoidosis. Increased spontaneous IL-1 release by AM was observed in 7 of 12 patients with active disease and in one of five with inactive disease $(p<$ 0.05 ) (figure 3 ). The autologous PBMNC in both groups did not release any detectable Il-1 spontaneously (figure 3 ). After LPS-stimulation the AM of active sarcoidosis released significantly higher amounts of IL-1 than did those of inactive disease. No difference concerning the stimulated release of PBMNC was observed in either group. To check for artifacts that might alter the IL-1 data obtained by the bioassay in four patients with active disease and TNF $\alpha$-positive alveolitis and in two patients with inactive disease and TNF $\alpha$ negative alveolitis, IL$1 \beta$ was measured by an ELISA. In all four patients with TNF $\alpha$ in the AM-supernatant IL-1 $\beta$ could be detected as well $(20$ 


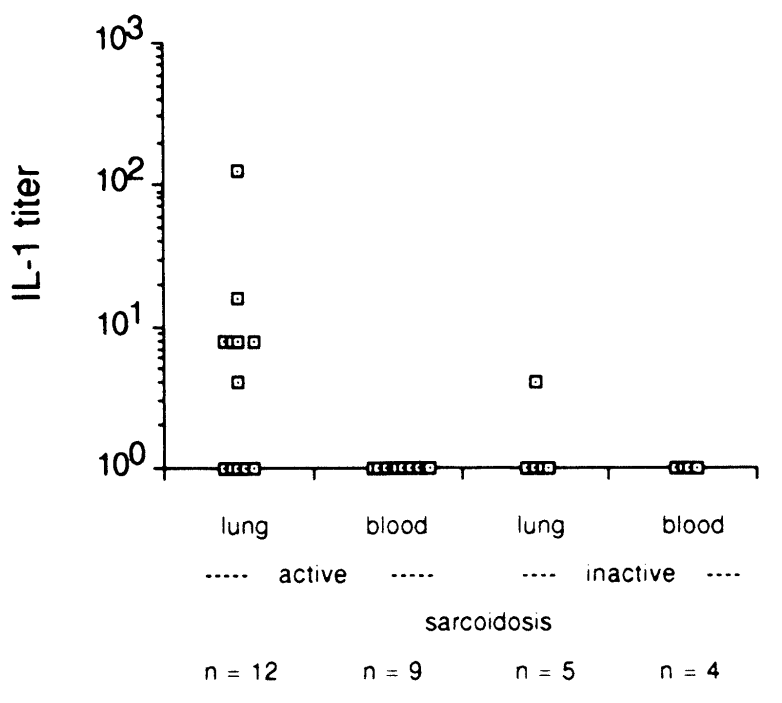

to $4,432 \mathrm{pg} / \mathrm{ml})$. No IL-1 was detectable in the supernatants of the two patients with inactive disease.

\section{Time-dependent Changes of}

Spontaneous TNFa Release by Alveolar Macrophages of

Patients with Active Sarcoidosis

To evaluate the hypothesis that heightened TNF $\alpha$ production by sarcoid AM in active disease may represent the consequence of a constitutive or a regulated activation of the cells, we investigated the time-dependent changes of spontaneous TNF $\alpha$ release 3 and $6 \mathrm{~h}$ after initiation of the cell culture. During the in vitro culture a considerable decrease of TNF $\alpha$ secretion was observed (figure 4). Although the highest amount of TNF $\alpha$ was released within the first $3 \mathrm{~h}$ after recovery of the cells, a significant decline was observed during the following $3 \mathrm{~h}$. However, when the cells were cultured in the presence of a stimulus they recurrently produced high levels of TNF $\alpha$.

To investigate TNF $\alpha$ gene expression in vitro as a function of time we evaluated AM for the presence of mRNA transcripts immediately after the cells were

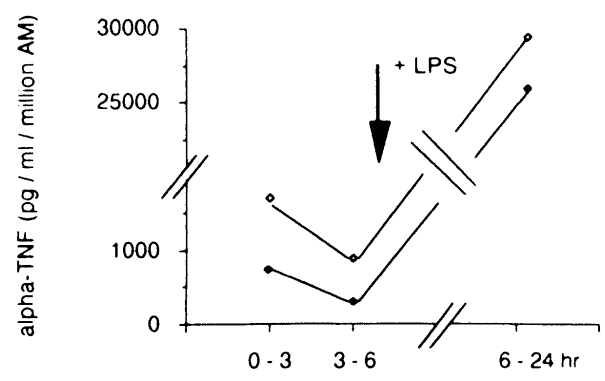

Fig. 4. Time-dependent changes of spontaneous TNF $\alpha$ release by sarcoid alveolar macrophages (AM) during in vitro culture. After $6 \mathrm{~h}, 1 \mu \mathrm{g} \mathrm{LPS} / \mathrm{ml}$ was added to the culture. (Two of two experiments are depicted.)
Fig. 3. Spontaneous IL-1 release by bronchoalveolar lavage cells (lung) and peripheral blood mononuclear cells (blood) of patients with active or inactive sarcoidosis. Control experiments were performed to demonstrate that in case of no spontaneous IL-1 release the cells :vere capable of secreting IL-1 after stimulation. In all control experiments an IL-1 release was observed after in vitro stimulation with $1 \mu \mathrm{g}$ LPS/ml (data not shown).

recovered from the lung and after $24 \mathrm{~h}$ in culture. Immediately after removal from the lung, the cells contained an abundance of TNF $\alpha$ transcripts (figure 5 , lane $0 \mathrm{hr}$ ). In the absence of stimulating agents, however, the amount of mRNA transcripts vanished over time (figure 5, lane $24 \mathrm{hr}$ ). In marked cont rast, the cells maintained their TNF $\alpha$ gene transcription during the entire culture period when cultured in the presence of a stimulus (figure 5, lane $24 \mathrm{hr}+$ LPS).

\section{Correlation between TNFa Release and Different Parameters of T-Cell Activation in Patients with Active Sarcoidosis}

Lung T-cells of patients with active sarcoidosis express typical signs of activation as spontaneous release of IL-2 and expression of IL-2R. Interactions of IL-2

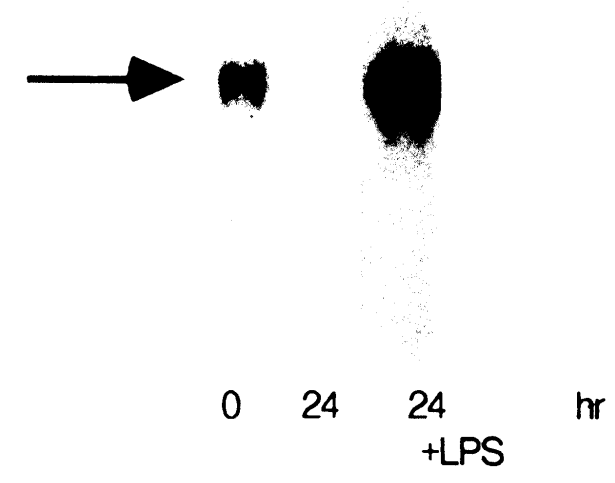

Fig. 5. Northern analysis of TNF $\alpha$ gene expression by sarcoid alveolar macrophages as a function of time. $\mathrm{Im}$. mediately after removal from the lung $(0 \mathrm{hr})$, after $24 \mathrm{~h}$ in vitro culture without $(24 \mathrm{hr})$ and with $1 \mathrm{mg} \mathrm{LPS} / \mathrm{ml}$ (24 hr + LPS). (One typical experiment of four is shown.) and its receptor with TNF $\alpha$ have been reported. Therefore, we investigated the correlation between spontaneous TNF $\alpha$ release by AM and spontaneous IL-2 release and IL-2R expression by BAL T-lymphocytes and soluble IL-2R serum levels in 21 patients with sarcoidosis (16 of the active and 5 of the inactive group). In none of the tested combinations could a correlation coefficient higher than 0.2 be observed. The correlation coefficient of TNF $\alpha /$ sIL-2R serum concentration was $0.06(n=22)$ (figure 6A), TNF $\alpha$ / IL-2R-positive BAL lymphocytes was $0.15(\mathrm{n}=36)$, (figure 6B), and TNF $\alpha /$ IL-2 release by BAL lymphocytes was $0.10(\mathrm{n}=21)$, (figure $6 \mathrm{C})$, respectively. To further analyze the interrelation between IL- 2 and TNF $\alpha$, we subdivided the patients according to their spontaneous IL-2/TNF $\alpha$ release. Eight of 21 patients produced $\mathrm{IL}-2\left(>1 \mathrm{U} / \mathrm{ml} / 10^{6} \mathrm{BAL}\right.$ T-cells $/ 24 \mathrm{~h})$ as well as TNF $\alpha(>700$
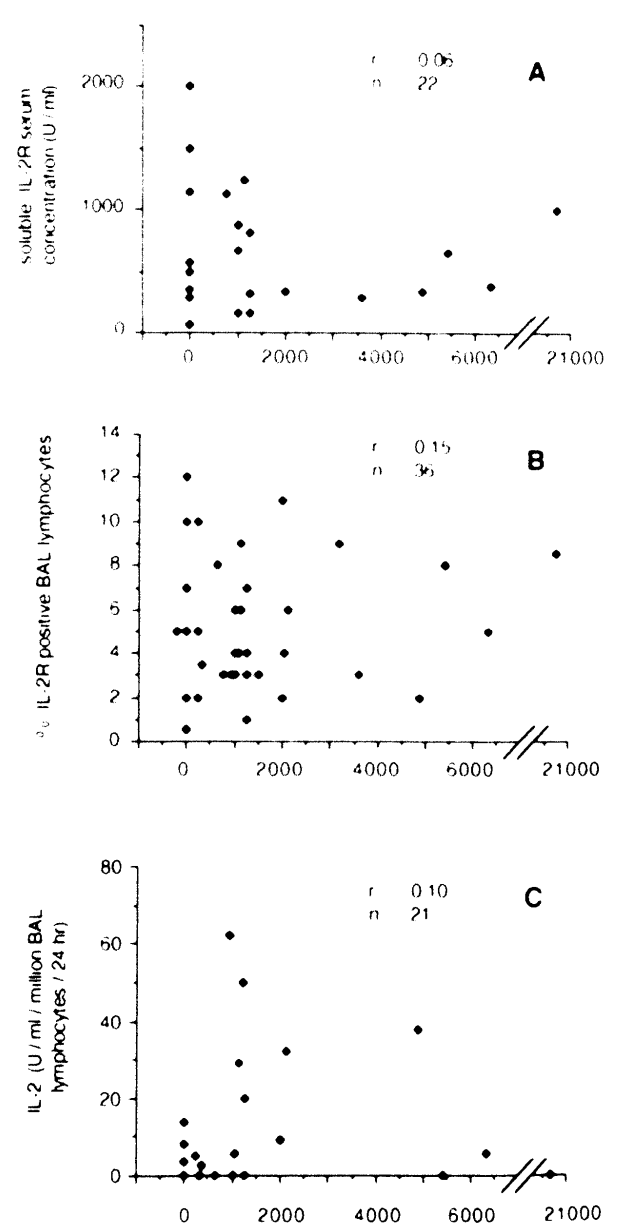

spontaneous alpha. TNF (pg/mi / million AM / $24 \mathrm{hr}$ )

Fig. 6. Correlation of different parameters of T-cell activation (soluble interleukin-2 receptor [IL-2R] serum concentration, percent surface IL-2R-positive lymphocytes in bronchoalveolar lavage [BAL] fluid, IL-2 release by BAL lymphocytes) with spontaneous TNFa release by sarcoid alveolar macrophages (AM). 
$\mathrm{pg} / \mathrm{ml} / 10^{6} \mathrm{AM} / 24 \mathrm{~h} ; 700 \mathrm{pg} / \mathrm{ml}$ corresponds to the mean plus 2 SD of 7 control subjects), 3 of 21 patients produced neither IL-2 nor TNF $\alpha, 7$ of 21 released TNF $\alpha$ but no IL-2, and 3 of 21 released IL-2 but no TNF $\alpha$.

In the inactive group alveolitis was positive in one patient for both mediators, in one patient for IL-2 only, and it was positive for any mediator in the remaining three patients. In the active group seven patients were positive for both cytokines, seven for TNF $\alpha$ but not for IL-2, and two were IL-2-positive but TNF $\alpha$-negative.

The patients with active disease exhibited an increased CD4/CD8 ratio together with a spontaneous TNF $\alpha$ release by AM. However, there was no correlation between these two parameters in either the active $(r=-0.08, n=28)$ or the inactive group $(r=-0.02, n=10)$.

\section{Discussion}

TNF $\alpha$ is an important biologic mediator that is secreted by activated AM and monocytes. In addition to activated T-cells, AM are the second but numerically dominating cell population in sarcoidosis. Our results confirm and extend the observation of the activation of these cells as reflected by their capacity for monokine release. The data presented demonstrate that AM of patients with active sarcoidosis spontaneously release significantly higher amounts of TNFa and IL-1 than do those of patients with inactive disease or control subjects. In the present study the heightened level of spontaneous TNF $\alpha$ secretion by AM was paralleled by an elevated spontaneous IL-1 release in 7 of 12 of the patients with active disease tested for both monokines. Our findings are in agreement with those of other investigators, who reported a significantly higher spontaneous release of TNF $\alpha$, Il-1, and $\gamma$-interferon by sarcoid AM than by normal $\operatorname{AM}(8,10,22)$. On the other hand, several investigators could nor demonstrate any differences between sarcoid and normal AM regarding the spontaneous secretion of the monokines TNF $\alpha$ and IL-1 $(9,13,23)$. These discrepancies might be explained by monokine inhibitors, which are known to be released by AM and which might influence the detection of these small amounts of monokines by bioassays (24, 25). As can be expected the spontaneous TNF $\alpha$ release by AM is not an exclusive characteristic of sarcoid alveolitis; it can be observed as well in diseases associated with AM activation by known or un- known agents such as tuberculosis and IPF. TNF $\alpha$ has been demonstrated to be involved in bleomycin- as well as silicainduced pulmonary fibrosis and in the generation of granulomata $(11,26)$.

In marked contrast to $\mathrm{AM}$, no differences between patients and control subjects emerged when the spontaneous monokine release by autologous PBMNC was tested. Our data suggest a restricted activation of the mononuclear phagocytes of the affected organ, i.e., the lung, whereas the mononuclear blood cells remain quiescent. This observation is corroborated by the study of Robinson and coworkers (8) who reported an increased $\gamma$-interferon release by sarcoid AM compared with that by normal AM. This spontaneous release appeared to be compartmentalized to the lung in that the blood mononuclear cells spontaneously released little or no $\gamma$-interferon (8). An in vitro anergy of sarcoid peripheral blood cells reflected in the reduced IL-1 and IL-2 production was observed by Hudspith and coworkers (27). Spatafora and colleagues (13) demonstrated small amounts of spontaneously produced TNF $\alpha$ by blood monocytes of sarcoid patients and normal control subjects, but without any difference between both. Using oxygen radical release to identify activated cells, it has been shown that sarcoid AM as well as peripheral blood monocytes are activated $(12,14)$. Regarding the monokine release, our data do not confirm this activation. Thus, the exaggerated oxygen radical release suggests a systemic monocyte activation in sarcoidosis. A feasible explanation of this contradiction may be seen in the shortterm activation of the monokine gene expression after cell stimulation $(1,3)$.

Studies on the molecular level demonstrated that maximal expression of TNF $\alpha$ gene is reached within $2 \mathrm{~h}$ after stimulation with LPS. Cytoplasmic TNF $\alpha$ was detected as early as $1 \mathrm{~h}$ after LPS stimulation, culminating during the next $2 \mathrm{~h}$ and followed by a decline (recently reviewed in 1 and 3). In this context our results indicate that the heightened spontaneous TNF $\alpha$ release in active sarcoidosis is the consequence of an in vivo activation step just prior to the removal of the cells from the lung. Because the highest amount of TNFa is produced during the first $3 \mathrm{~h}$ of in vitro culture followed by a sharp decline, it can be concluded that TNF $\alpha$ release is regulated in a physiologic manner in those cells and that the putative agent causing sarcoidosis does not interfere with the regula- tion of the TNF $\alpha$ gene (figure 4). This concept is further corroborated by the decay of TNF $\alpha$ mRNA in the in vitro culture in the absence of any stimulation (figure 5).

Our observation that LPS-stimulated sarcoid AM of patients with active sarcoidosis produce significantly more TNF $\alpha$ than do AM of normal subjects and of those with inactive disease is in accordance with the literature and suggests that in sarcoidosis AM become primed locally $(9,13)$. The increased ability to secrete TNF $\alpha$ after endotoxin stimulation may represent an additional marker of activation that is restricted to the lung. However, the mechanism by which sarcoid AM are primed for elevated TNF $\alpha$ secretion remains open. Cytokines such as interleukin- 2 and $\gamma$-interferon, which are produced locally by activated lung T-cells in sarcoidosis may represent the initiative agents of TNF $\alpha$ production. In human blood monocytes and AM, IL-2 is a strong signal for TNF $\alpha$ induction (2). We therefore investigated the interrelation between IL-2 and TNF $\alpha$, which are both spontaneously released in patients with active disease. Unexpectedly, we could not establish a correlation between these two parameters $(r=0.1)$ Eight of $21(38 \%)$ patients released both cytokines simultaneously, whereas 7 of $21(33 \%)$ secreted only TNFa, 3 of $21(14 \%)$ only IL-2, and 3 of $21(14 \%)$ neither of both. The finding of induction of TNF $\alpha$ by IL-2 has established an additional lymphokine-macrophage link (2), but currently the role of IL-2 in the induction of TNF $\alpha$ in pulmonary sarcoidosis remains a subject of speculation. In addition to the lacking correlation between IL-2 and TNF $\alpha$, we could not find any correlation between TNF $\alpha$ and other markers of T-cell activation such as IL-2R surface expression by BAL T-lymphocytes and soluble IL-2R serum concentration, which represent useful tools for measuring T-cell activation (28) as well as clinical activity of the disease (29). It is interesting to observe that in only 7 of 16 patients with active sarcoidosis, TNFa and IL-2 are simultaneously released by the alveolar immune cells.

Accessory functions that are provided by the cells of the mononuclear phagocytic lineage are required by most types of cellular and immune processes. The observation that these cells are compartmentalized and activated to release large amounts of monokines such as IL-1 and $\mathrm{TNF} \alpha$ spontaneously therefore suggests that they participate in the pathogenesis 
of sarcoidosis not only as a building block in the formation of granulomata but also in the maintenance of the inflammatory processes characteristic of the disorder.

\section{References}

1. Rosenblum GR, Donato NJ. Tumor necrosis factor a: a multifaceted hormone. Crit Rev Immunol 1989; 9:21-44.

2. Strieter RM, Remick DG, Lynch JP, Sprengler $\mathrm{RN}$, Kunkel SL. Interleukin-2-induced tumor necrosis factor-alpha gene expression in human alveolar macrophages and blood monocytes. Am Rev Respir Dis $1989 ; 139: 335-42$.

3. Kunkel SL, Remick DG, Strieter RM, Larrick JW. Mechanisms that regulate the production and effects of tumor necrosis factor- $\alpha$. Crit Rev Immunol 1989; 9:93-117.

4. Hudspith BN, Flint KC, Geraint-James D, Brostoff J, McI Johnson N. Lack of immune deficiency in sarcoidosis: compartmentalisation of the immune response. Thorax 1987; 42:250-5.

5. Hunninghake GW, Bedell GN, Zavala DC, Monick M, Brady M. Role of interleukin-2 release by lung T-cells in active pulmonary sarcoidosis. Am Rev Respir Dis 1983; 128:634-6.

6. Müller-Quernheim J, Saltini C, Sondermeyer P, Crystal RG. Compartmentalized activation of the interleukin-2 gene by lung T-lymphocytes in active pulmonary sarcoidosis. J Immunol 1986; 137:3475-83.

7. Pinkston P, Bitterman PB, Crystal RG. Spontaneous release of interleukin- 2 by lung T-lymphocytes in active pulmonary sarcoidosis. N Engl J Med 1983; 308:793-800.

8. Robinson BWS, McLemore T, Crystal RG. Gamma interferon is spontaneously released by alveolar macrophages and lung T-lymphocytes in patients with pulmonary sarcoidosis. J Clin Invest 1985; 75:1488-95.
9. Bachwich PR, Lynch JP, Larrick JW, Spengler M, Kunkel SL. Tumor necrosis factor production by human sarcoid alveolar macrophages. Am J Pathol 1986; 125:421-5.

10. Hunninghake GW. Release of interleukin-1 by alveolar macrophages of patients with active pulmonary sarcoidosis. Am Rev Respir Dis 1984; 129:569-72.

11. Kunkel SL, Chensue SW, Strieter RM, Lynch JP, Remick DG. Cellular and molecular aspects of granulomatous inflammation. Am J Respir Cell Mol Biol 1989; 1:439-47.

12. Fels AOS, Nathan CF, Cohn ZA. Hydrogen peroxide release by alveolar macrophages from sarcoid patients and by alveolar macrophages from normals after exposure to recombinant interferons alpha, beta and gamma and 1,25-dihydroxyvitamin D3. J Clin Invest 1987; 80:381-6.

13. Spatafora M, Merendino A, Chiappara G, et al. Lung compartmentalization of increased TNF releasing ability by mononuclear phagocytes in pulmonary sarcoidosis. Chest 1989; 96:542-9.

14. Kanegasaki S, Homma JY, Homma $\mathrm{H}$, Washizaki M. Enhanced chemiluminescence response of phagocyting monocytes from sarcoidosis patients. Int Arch Allergy Appl Immunol 1981; 64:72-9.

15. Thomas PD, Hunninghake GW. Current concepts of pathogenesis of sarcoidosis. Am Rev Respir Dis 1987; 135:747-60.

16. Hunninghake GW, Fulmer JD, Young RC, Gadek JE, Crystal RG. Localisation of the immune response in sarcoidosis. Am Rev Respir Dis 1979; 120:49-57.

17. Böyum A. Isolation of mononuclear cells and granulocytes from human blood. Scand J Lab Clin Invest Suppl 1968; 21:77-89.

18. Kist A, Ho AD, Räth U, et al. Decrease of natural killer cell activity and monokine production in peripheral blood of patients treated with recombinant tumor necrosis factor. Blood 1988; 72:344-8. 19. Falk W, Krammer PH, Männel DN. A new assay for interleukin-l in the presence of interleukin-2. J Immunol Methods 1987; 99:47-52.
20. Magaud JP, Sargent I, Mason DY. Detection of human white cell proliferative response by immunoenzymatic measurement of bromodeoxyuridine uptake. J Immunol Methods 1988; 106:95-100. 21. Farrar JJ, Mizel SB, Fuller-Farrar J, Farrar WL, Hilfiker ML. Macrophage independent activation of $\mathrm{T}$ cells. I. Production of interleukin 2. J Immunol 1980; 125: 793-8.

22. Baughman RP, Strohofer SA, Buchsbaum J, Lower EE. Release of tumor necrosis factor by alveolar macrophages of patients with sarcoidosis. J Lab Clin Med 1990; 115:36-42.

23. Wewers MD, Saltini C, Sellers S, et al. Evaluation of alveolar macrophages in normals and individuals with active pulmonary sarcoidosis for the spontaneous expression of interleukin-1 $\beta$ gene. Cell Immunol 1987; 107:479-88.

24. Seckinger $P, Z$ hang JH, Hauptmann $B$, Dayer JM. Characterisation of tumor necrosis factor $\alpha$ (TNF- $\alpha$ ) inhibitor: evidence of immunological cross-reactivity with the TNF receptor. Proc Natl Acad Sci USA 1990; 87:5188-92.

25. Dayer JM. Cytokines and cytokine inhibitors in inflammation. Eur Respir J 1990; 3(Suppl 10:178s).

26. Piguet PF, Collart MA, Grau GE, Sappino $A P$, Vassalli P. Requirement of tumor necrosis factor for development of silica-induced pulmonary fibrosis. Nature 1990; 344:245-7.

27. Hudspith BN, Brostoff J, McNicol MW, Johnson NM. Anergy in sarcoidosis: the role of interleukin-1 and prostaglandins in the depressed in vitro lymphocyte response. Clin Exp Immunol 1984; 57:324-30.

28. Müller-Quernheim J, Krönke M, Strausz J, Schykowski M, Ferlinz R. Interleukin-2 receptor gene expression by bronchoalveolar lavage lymphocytes in pulmonary sarcoidosis. Am Rev Respir Dis $1989 ; 140: 82-8$.

29. Lawrence EC, Brousseau KP, Berger MB, Kurman CC, Marcon L, Nelson DL. Elevated concentration of soluble interleukin-2 receptors in serum samples and bronchoalveolar fluids in active sarcoidosis. Am Rev Respir Dis 1988; 137:759-64. 